\title{
Predictive value of HER2 serum levels in patients treated with lapatinib or trastuzumab - a translational project in the neoadjuvant GeparQuinto trial
}

\section{Witzel', S Loibl', G von Minckwitz ${ }^{2}$, H Eidtmann ${ }^{3}$, T Fehm ${ }^{4}$, F Khandan ${ }^{5}$, S Schmatloch ${ }^{6}$, M Hauschild ${ }^{7}$, J Bischoff ${ }^{8}$, PA Fasching', C Mau ${ }^{10}$, C Schem ${ }^{3}$, B Rack ${ }^{11}$, I Meinhold-Heerlein ${ }^{12}$, C Liedtke ${ }^{13}$, T Karn ${ }^{14}$, J Huober ${ }^{15}$, C zu Eulenburg ${ }^{16}$, Y Issa-Nummer ${ }^{2}, M$ Untch $^{10}$ and V Müller, ${ }^{*, 1}$}

'Department of Gynecology, University Medical Center Hamburg-Eppendorf, 20246 Hamburg, Germany; ${ }^{2}$ German Breast Group, 63263 Neu-lsenburg, Germany; ${ }^{3}$ Department of Gynecology and Obstetrics, University Medical Center Schleswig-Holstein, Campus Kiel, 24 I I 8 Kiel, Germany; ${ }^{4}$ Department of Gynecology and Obstetrics, University Medical Center Tübingen, 72076 Tübingen, Germany; ${ }^{5}$ Markus Krankenhaus, 60431 Frankfurt am Main, Germany; ${ }^{6}$ Breast Center, Elisabeth-Hospital, 34117 Kassel, Germany; ${ }^{7}$ Frauenklinik Gesundheitszentrum Fricktal, 4310 Rheinfelden, Switzerland; ${ }^{8}$ Department of Gynecology and Obstetrics, University Hospital, 39120 Magdeburg, Germany; ${ }^{9}$ Department of Gynecology and Obstetrics, University Hospital Erlangen, Friedrich-Alexander University Erlangen-Nuremberg, Comprehensive Cancer Center Erlangen-Nuremberg, 91054 Erlangen, Germany; ${ }^{10}$ Interdisciplinary Breast Cancer Center, Helios Klinikum Berlin Buch, 13125 Berlin, Germany; "Department of Gynecology and Obstetrics, LudwigMaximilians-University Munich, Campus Innenstadt, 80539 Munich, Germany; ${ }^{12}$ Department of Gynecology and Obstetrics, University Hospital Aachen, 52074 Aachen, Germany; ${ }^{13}$ Department of Gynecology and Obstetrics, University Hospital, 48149 Muenster, Germany; ${ }^{14}$ Department of Gynecology and Obstetrics, University Hospital Frankfurt, 60590 Frankfurt am Main, Germany; ${ }^{15}$ Breast Center, Cantonal Hospital, 9007 St.Gallen, Switzerland;

${ }^{16}$ Department of Medical Biometry and Epidemiology, University Medical Center Hamburg-Eppendorf, 20246 Hamburg, Germany

BACKGROUND: We were able to demonstrate a predictive value of serum HER2 (sHER2) in patients receiving trastuzumab in the neoadjuvant GeparQuattro trial. However, the role of sHER2 in patients receiving neoadjuvant therapy (NT) with lapatinib is still unclear.

METHODS: The neoadjuvant GeparQuinto trial compared trastuzumab vs lapatinib in addition to chemotherapy in HER2-positive primary breast cancer patients. The sHER2 levels were measured by enzyme-linked immunosorbant assay in 210 patients, of whom I09 (52\%) patients received trastuzumab and 10 I (48\%) lapatinib at three different time points.

RESULTS: Twenty-two percent of patients had elevated baseline sHER2 levels (>15 ng ml ${ }^{-1}$ ). A decrease of sHER2 levels (>20\%) in the trastuzumab and lapatinib-treated group during NT was seen in $44 \%$ and $24 \%$ of the patients, an increase of sHER2 levels (>20\%) was seen in $6 \%$ and $41 \%$ of patients, respectively. Higher pre-chemotherapy sHER2 levels were associated with higher pathological complete remission ( $P C R$ ) rates in the entire study cohort (OR 1.8, 95\% Cl 1.02-3.2, P=0.043). A decline of sHER2

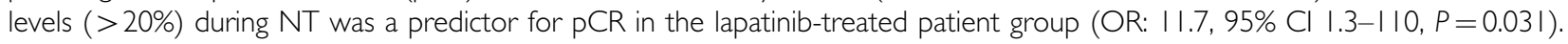
CONCLUSION: Results of this study demonstrate that sHER2 levels change differently during NT depending on the anti-HER2 treatment strategy. Elevated baseline sHER2 levels $\left(>15 \mathrm{ng} \mathrm{ml}^{-1}\right.$ ) and a decrease of sHER2 levels (>20\%) early after therapy initiation are both relevant criteria to predict response to lapatinib-based treatment.

British Journal of Cancer (2012) 1 07, 956-960. doi:I0.1038/bjc.20 I 2.353 www.bjcancer.com

Published online 14 August 2012

(C) 2012 Cancer Research UK

Keywords: breast cancer; neoadjuvant therapy; HER2; serum; trastuzumab; lapatinib

Neoadjuvant therapy (NT) strategies allow an early assessment of treatment effects in breast cancer patients without long follow-up as required in the adjuvant setting. This is an opportunity for translational research projects examining biomarkers that should improve the understanding of mechanisms underlying treatment response. In the phase III GeparQuinto trial, patients with a HER2positive primary tumour were randomly assigned to receive either

*Correspondence: Professor Dr V Müller; E-mail: vmueller@uke.de Part of this work was presented at the San Antonio Breast Cancer Conference in San Antonio, TX, USA in December 2011.

Received I June 2012; revised 16 July 2012; accepted 16 July 2012; published online 14 August 2012 trastuzumab or lapatinib in addition to four cycles of epirubicin/ cyclophosphamide followed by four cycles of docetaxel (von Minckwitz et al, 2011; Untch et al, 2012).

Trastuzumab, a monoclonal antibody directed against the extracellular domain of HER2, has become a standard treatment in HER2-positive breast cancer in the adjuvant and neoadjuvant setting, increasing the pathological complete remission (pCR) rate significantly to around 40\% (Buzdar et al, 2005; Untch et al, 2010, 2011). Lapatinib, an inhibitor of the intracellular tyrosine kinases of HER1 and HER2, has shown efficacy in metastatic breast cancer and is currently examined in early breast cancer (MacFarlane and Gelmon, 2011; Baselga et al, 2012).

The extracellular domain of the HER2 protein can be cleaved from the surface by metalloproteases and detected in the 
peripheral blood as serum HER2 (sHER2) (Codony-Servat et al, 1999; Tse et al, 2011). It was reported that the remaining cleaved HER2 receptor is constitutively activated (Hudelist et al, 2003), suggesting that the presence of sHER2 also reflects a biological process leading to a more aggressive tumour behaviour (Molina et al, 2002). Elevated levels of sHER2 are observed in patients with primary or metastatic breast cancer (Mueller et al, 2004; Witzel et al, 2010). Trastuzumab inhibits shedding of HER2 (Molina et al, 2001). In contrast, lapatinib was reported to enhance shedding of HER2 with an elevation of sHER2 levels in vitro (Vazquez-Martin et al, 2011), indicating a different mechanism of action. This could potentially lead to different sHER2 levels in patients treated with trastuzumab or lapatinib. In the previous GeparQuattro trial, we could demonstrate that sHER2 levels were a predictor for pCR in trastuzumab-treated patients (Witzel et al, 2010). However, the role of sHER2 in lapatinib-treated patients is still unclear. Therefore, we examined sHER2 levels in the context of neoadjuvant lapatinib treatment in the GeparQuinto trial.

\section{MATERIAL AND METHODS}

\section{The clinical study GeparQuinto}

A total of 620 patients were scheduled to receive four cycles of EC (epirubicin $90 \mathrm{mg} \mathrm{m}^{-2}$, cyclophosphamide $600 \mathrm{mg} \mathrm{m}^{-2}$, day 1 , every 3 weeks) followed by four cycles of docetaxel $\left(100 \mathrm{mg} \mathrm{m}^{-2}\right.$, day 1 , every 3 weeks). Patients were randomly assigned to receive trastuzumab $6 \mathrm{mg} \mathrm{kg}^{-1}$ intravenously, every 3 weeks, starting with a loading dose of $8 \mathrm{mg} \mathrm{kg}^{-1}$ intravenously on day 1 of the first EC cycle or lapatinib $1250 \mathrm{mg}$ per day starting on day 1 of the first cycle of EC until day 21 of the fourth cycle of docetaxel concomitantly to all chemotherapy cycles. Patients completed 1 year of anti-HER2 treatment with trastuzumab post surgery in both treatment groups.

\section{Inclusion criteria for the translational subprotocol and ethical considerations}

Full blood samples were collected for patients eligible for the GeparQuinto study in the participating centres at three different time points: before initiation of NT, after four cycles of epirubicin and cyclophosphamide and prior to surgery (Figure 1). Samples were stored at $-20^{\circ} \mathrm{C}$ and shipped on dry ice. All the patients gave written informed consent to blood collection as part of the correlative science programme, before entering the GeparQuinto study. Participation in the clinical trial was still possible even if a patient did not agree to participate in the correlative science

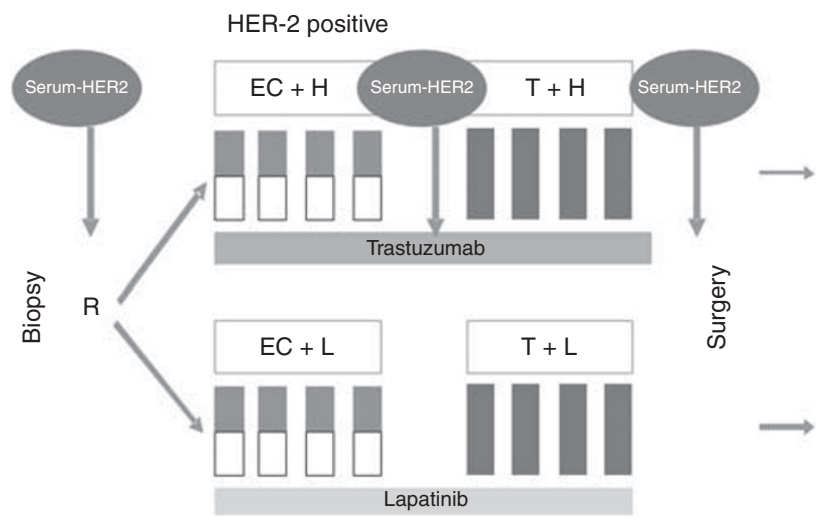

Figure I Serum collection in the HER2-positive patient cohort in the GeparQuinto trial. Abbreviations: $C=$ cyclophophamide; $E=$ epirubicin; $\mathrm{H}=$ trastuzumab; $\mathrm{L}=$ lapatinib and $\mathrm{T}=$ docetaxel. programme. Patients were not informed about the laboratory results because of their experimental character. The clinical study as well as the translational research project described here were approved by the competent ethics committees. The disposition of patients (CONSORT diagram) is shown in Supplementary Figure 1.

\section{Interventions}

Serum samples from patients in study centres having agreed to biomaterial collection were send to the central laboratory of the German Breast Group. Correct labelling was checked and 210 serum samples (109 of patients in the trastuzumab arm and 101 of patients in the lapatinib arm) were forwarded to the Department of Gynecology, University Medical Center Hamburg-Eppendorf. The sHER2 assay was performed blinded for the clinical results. Detailed patient characteristics are listed in Table 1. No relevant differences between the patient characteristics of the full study population and the analysed subgroup were observed (data not shown).

\section{Enzyme-linked immunosorbant assay (ELISA)}

The sHER2 was quantified by a commercially available ELISA (Wilex Inc, Cambridge, MA, USA) as previously described (Mueller et al, 2004). The results were expressed in $\mathrm{ng} \mathrm{ml}^{-1}$. Each sample, standard and control, was assayed in duplicate. Inter-assay and intra-assay coefficients of variation were $<10 \%$. A currently used cut-off in the metastatic setting and also recommended by the manufacturer of the assay is $15 \mathrm{ng} \mathrm{ml}^{-1}$ (Esteva et al, 2002; Lipton et al, 2002). Therefore, serum levels $>15 \mathrm{ng} \mathrm{ml}^{-1}$ were regarded as elevated. As a decrease of sHER2 levels of $>20 \%$

Table I Baseline characteristics before neoadjuvant therapy and tumour response of patients with HER2-positive tumours in the trastuzumab and lapatinib group

\begin{tabular}{|c|c|c|c|c|}
\hline \multirow[b]{2}{*}{ Parameter } & \multicolumn{2}{|c|}{ Trastuzumab } & \multicolumn{2}{|c|}{ Lapatinib } \\
\hline & No. & $\%$ & No. & $\%$ \\
\hline \multicolumn{5}{|l|}{ Tumour size } \\
\hline TI & 16 & 15.4 & 11 & 11.2 \\
\hline $\mathrm{T} 2$ & 50 & 48.1 & 45 & 45.9 \\
\hline $\mathrm{T} 3$ & 18 & 17.3 & 27 & 27.6 \\
\hline $\mathrm{T} 4 \mathrm{a}-\mathrm{c}$ & 7 & 6.7 & 4 & 4.1 \\
\hline $\mathrm{T} 4 \mathrm{~d}$ & 13 & 12.5 & 11 & 11.2 \\
\hline Missing & 6 & & 3 & \\
\hline \multicolumn{5}{|l|}{ Grading } \\
\hline GI & 1 & 0.9 & 1 & 1.0 \\
\hline G2 & 53 & 48.2 & 48 & 46.2 \\
\hline G3 & 56 & 51.8 & 55 & 52.8 \\
\hline \multicolumn{5}{|l|}{ Hormone receptor status } \\
\hline ER positive/PR positive & 38 & 34.5 & 41 & 39.4 \\
\hline ER positive/PR negative & 50 & 45.5 & 46 & 44.2 \\
\hline ER negative/PR positive & 3 & 2.7 & 4 & 3.8 \\
\hline ER negative/PR negative & 19 & 17.3 & 13 & 12.5 \\
\hline \multicolumn{5}{|l|}{ Clinical nodal status } \\
\hline Negative & 33 & 35.5 & 33 & 34.0 \\
\hline Positive & 69 & 64.5 & 64 & 66.0 \\
\hline Missing & 2 & & 4 & \\
\hline \multicolumn{5}{|l|}{$p C R$} \\
\hline Yes & 40 & 36 & 25 & 24 \\
\hline No & 70 & 64 & 79 & 76 \\
\hline
\end{tabular}

Abbreviations: $E R=$ oestrogen receptor; $\mathrm{pCR}=$ pathological complete remission; $\mathrm{PR}=$ progesterone receptor. 
during NT revealed significant results in the preceding GeparQuattro trial, we used the same cut-off (20\%) for this analysis. We defined an increase of $20 \%$ during NT as significant in concordance to previous reports in metastatic breast cancer (Lipton et al, 2011).

\section{Statistical analysis}

The statistical analysis was performed using PASW Statistics 19.0 software (IBM, Armonk, NY, USA). The sHER2 levels were logarithmised for the analysis. A more than $20 \%$ change in sHER2 during therapy was defined as a significant change (Ali et al, 2008). The sHER2 levels were plotted against clinicopathological parameters by analysis of variance. The following groups were compared: tumour size $<5 \mathrm{~cm}(\mathrm{cT} 1+2) v s>5 \mathrm{~cm}$ $(\mathrm{cT} 3+4)$; G1/G2 vs G3; node-positive vs node-negative tumours; oestrogen receptor (ER) positive $v s$ ER negative, progesterone receptor (PR) positive vs $\mathrm{PR}$ negative; and trastuzumab- $v s$ lapatinib-treated patient cohort. Pathological complete remission was defined as no microscopic evidence of invasive and noninvasive residual tumour in the breast and lymph nodes. The correlation between pCR and baseline variables was tested by logistic regression in the univariate and multivariate analysis. A two-tailed $P$-value $<0.05$ was considered as statistically significant. Each analysis was also done separately for the trastuzumaband lapatinib-treated patients. The study was performed in accordance to the REMARK criteria published and discussed (McShane et al, 2005; Hayes et al, 2006). The end point for our analysis was the clinical end point of the study, the pCR as defined by the protocol, in correlation with absolute values and changes of sHER2 levels.

\section{RESULTS}

A total of 210 patients were included in this analysis. There was no difference between trastuzumab- and lapatinib-treated patients regarding median age, tumour size, nodal status and grading. Only rate of pCR differed between trastuzumab- and lapatinib-treated patients (36\% for trastuzumab vs $24 \%$ for lapatinib, Table 1$)$.

\section{Serum HER2 levels}

In all, $22(20 \%)$ patients treated with trastuzumab and $24(23 \%)$ patients treated with lapatinib had elevated sHER2 levels $>15 \mathrm{ng} \mathrm{ml}^{-1}$ before chemotherapy. The median sHER2 levels before treatment were $9.9 \mathrm{ng} \mathrm{ml}^{-1}$ in both treatment arms. The median sHER2 level did not change significantly during trastuzumab therapy ( $8.8 \mathrm{ng} \mathrm{ml}^{-1}$ after four cycles of NT, $8.6 \mathrm{ng} \mathrm{ml}^{-1}$ pre-surgery) but increased slightly during lapatinib treatment $\left(11.7 \mathrm{ng} \mathrm{ml}^{-1}\right.$ after four cycles of NT, $10.7 \mathrm{ng} \mathrm{ml}^{-1}$ pre-surgery). The sHER2 levels after four cycles of NT and pre-surgery were higher in the lapatinib than in the trastuzumab group $(P<0.001)$.

\section{Change of sHER2 levels during chemotherapy}

The rate of patients with a decline of sHER2 levels ( $>20 \%$ ) after the first four cycles of NT was higher in the trastuzumab-treated group than the lapatinib-treated group $(P=0.001)$. A total of 48 $(44 \%)$ trastuzumab-treated patients and $25(24 \%)$ lapatinib-treated patients showed a decline of sHER2 levels $(>20 \%)$ at this time point. A further decline of sHER2 levels between four cycles to presurgery was observed in $21(19 \%)$ trastuzumab-treated patients and $29(28 \%)$ lapatinib-treated patients $(P=0.20)$.

An increase of sHER2 levels $(>20 \%)$ during the first four cycles of chemotherapy was seen in $7(6 \%)$ trastuzumab-treated patients, $43(41 \%)$ lapatinib-treated patients $(P<0.001)$ and between four cycles to pre-surgery in $15(14 \%)$ and $9(9 \%)$ patients, respectively, $(P=0.28)$ (Figure 2).

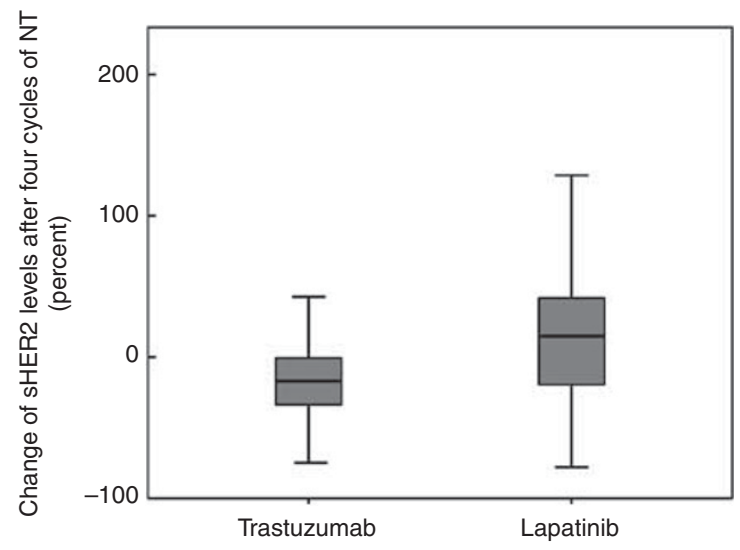

Figure 2 Box plot of sHER2 changes after four cycles of chemotherapy in trastuzumab- and lapatinib-treated patients. Patients in the trastuzumab group experienced mainly sHER2 decreases, whereas in the lapatinib group, a significant number of sHER2 increases was observed.

Table 2 sHER2 levels at three different time points

\begin{tabular}{|c|c|c|c|c|c|c|}
\hline \multirow[b]{2}{*}{$\begin{array}{l}\text { Baseline } \\
\text { characteristics }\end{array}$} & \multicolumn{2}{|c|}{$\begin{array}{l}\text { sHER2 pre- } \\
\text { chemotherapy }\end{array}$} & \multicolumn{2}{|c|}{$\begin{array}{l}\text { sHER2 after } \\
\text { four cycles of } \\
\text { chemotherapy }\end{array}$} & \multicolumn{2}{|c|}{$\begin{array}{l}\text { sHER2 before } \\
\text { surgery }\end{array}$} \\
\hline & $\begin{array}{c}\text { Mean } \\
\left(\mathrm{ng} \mathrm{ml}^{-1}\right)\end{array}$ & $P$-value & $\underset{\left(\mathrm{ng} \mathrm{ml}^{-1}\right)}{\text { Mean }}$ & $P$-value & $\underset{\left(\mathrm{ng} \mathrm{ml}^{-1}\right)}{\text { Mean }}$ & $P$-value \\
\hline $\mathrm{T} 3 / 4$ & 17.7 & $<0.001$ & 10.8 & n.s. & 9.9 & n.s. \\
\hline $\mathrm{TI} / 2$ & 11.1 & & 10.3 & & 9.9 & \\
\hline G3 & 4.5 & n.s. & 10.8 & n.s. & 10.1 & n.s. \\
\hline $\mathrm{G} \mid / 2$ & 12.5 & & 10.3 & & 9.7 & \\
\hline $\mathrm{cNI}$ & 14.9 & 0.008 & 10.6 & n.s. & 9.8 & n.s. \\
\hline cNO & 10.3 & & 10.3 & & 10.0 & \\
\hline ER negative & 15.6 & $<0.001$ & 10.9 & n.s. & 9.8 & n.s. \\
\hline ER positive & 11.6 & & 10.2 & & 9.9 & \\
\hline
\end{tabular}

Abbreviations: $E R=$ oestrogen receptor; n.s. = not significant.

\section{Correlation between sHER2 levels and clinicopathological parameters}

Higher sHER2 levels before chemotherapy were correlated with negative ER status $(P<0.001)$. A positive correlation was observed between sHER2 levels and positive nodal status $(P<0.008)$ and larger tumour size $(P<0.001)$.

No other correlations between clinicopathological parameters, including age, grading, histological type, PR status and prechemotherapy sHER2 levels or sHER2 levels after four and eight cycles of chemotherapy, were observed (Table 2).

\section{Pathological complete remission in relation to sHER2 levels and clinicopathological parameters}

Regarding the entire patient cohort, an association between pCR and negative hormone receptor status $(P=0.01$ for $\mathrm{ER}$ and $P=0.032$ for PR), higher pre-chemotherapy sHER2 levels $(P=0.043)$ and a decline of sHER2 levels $(>20 \%)$ after four cycles of chemotherapy $(P=0.049)$ in univariate analysis were observed. We could demonstrate linearity between pre-chemotherapy sHER2 levels and the probability of a pCR, but could not define a specific cut-off level for sHER2 to predict pCR.

In the trastuzumab-treated patient cohort, a decrease of sHER2 levels $(>20 \%$ ) during NT (before therapy to after four cycles of chemotherapy) was associated with $\mathrm{pCR}$ in univariate analysis $(P=0.046)$, which was not significant in multivariate analysis (OR: 2.76, 95\% CI $0.91-8.35, P=0.07$, Table 3) adjusted for prechemotherapy sHER levels, tumour size, nodal status, grading and ER status. 
Table 3 Correlation of clinicopathological parameters with $\mathrm{PCR}$ in the trastuzumab-treated and lapatinib-treated patient group (multivariate analysis)

\begin{tabular}{|c|c|c|c|c|}
\hline \multirow[b]{2}{*}{ Baseline characteristics } & \multicolumn{2}{|c|}{ Trastuzumab } & \multicolumn{2}{|c|}{ Lapatinib } \\
\hline & $\begin{array}{l}\text { Odds } \\
\text { ratio }\end{array}$ & $P$-value & $\begin{array}{l}\text { Odds } \\
\text { ratio }\end{array}$ & $P$-value \\
\hline T3/4 vs TI/2 & 2.1 & 0.15 & 0.71 & 0.59 \\
\hline G3 vs GI/2 & 1.9 & 0.18 & 1.22 & 0.73 \\
\hline cNO vs cNI & 2.2 & 0.12 & 3.78 & 0.033 \\
\hline HR positive vs HR negative & 0.5 & 0.17 & 0.21 & 0.013 \\
\hline Pre-chemotherapy sHER2 levels & 1.5 & 0.49 & 10.8 & 0.01 \\
\hline $\begin{array}{l}\text { sHER } 2 \text { decrease }>20 \% \text { vs sHER } 2 \\
\text { decrease } \leqslant 20 \%\end{array}$ & 2.76 & $P=0.07$ & 11.7 & 0.031 \\
\hline
\end{tabular}

Abbreviations: $H R=$ hormone receptor; $p C R=$ pathological complete remission; sHER2 $=$ serum HER2.

In the lapatinib-treated patient cohort, negative ER status $(P=0.025)$ was associated with PCR in univariate analysis. However, in the multivariate analysis, higher pre-chemotherapy sHER2 levels (OR: $10.7,95 \%$ CI 1.7-65, $P=0.01$ ), as well as a decrease of sHER2 levels $(>20 \%)$ after four cycles of NT (OR: 11.7, 95\% CI 1.3-110, $P=0.031$ ), were associated with pCR. In addition, patients with negative ER status and positive nodal status showed higher pCR rates in multivariate analysis adjusted for tumour size and grading (Table 3). An increase of sHER2 levels during therapy $(>20 \%)$ was not associated with pCR in both groups (data not shown).

\section{DISCUSSION}

In this prospective evaluation of sHER2 levels in patients treated with either trastuzumab or lapatinib in the neoadjuvant GeparQuinto trial, we observed that a decrease of sHER2 levels during therapy was associated with pCR in the lapatinib-treated patient group. However, sHER2 levels increased more frequently during lapatinib compared with trastuzumab treatment.

To the best of our knowledge, this is the first study on sHER2 levels in patients treated with lapatinib in the neoadjuvant setting. In the previous GeparQuattro trial applying only trastuzumab for HER2-positive patients, we observed that elevated sHER2 levels before and a decrease of $>20 \%$ during NT (measured before and after NT) were associated with pCR (Witzel et al, 2010). In the current GeparQuinto trial comparing the two different anti-HER2 treatment strategies trastuzumab and lapatinib, we found also in lapatinib-treated patients that sHER2 levels are a potential predictor of PCR in addition to their effect in trastuzumab-treated patients.

Recently, results of large NT trials comparing different HER2targeted therapy strategies were published (Baselga et al, 2012; Gianni et al, 2012). However, predictive markers to choose between different therapeutic options and a profound understanding of the mechanisms underlying the action of these approaches are missing.

The biological relevance of elevated sHER2 is still unknown. Some studies have suggested a better response to trastuzumab in patients with HER2-positive tumours and elevated sHER2 levels (Köstler et al, 2004; Witzel et al, 2010), whereas other studies have reported limited predictive utility for sHER2 (Mazouni et al, 2007). High sHER2 levels might also indicate increased HER2 cleavage and shedding. An activation of the signalling kinase domain through HER2 shedding could be mediated via truncated cell-associated fragments of HER2 and a consecutively deregulated growth-promoting pathway (Baselga, 2001). This hypothesis is based on the increased signalling of the p95 subunit of HER2 in cleaved HER2 receptors. The p95 protein is the intracellular component of HER2 that remains after shedding of the extracellular domain and contains the kinase domain.
Some studies suggested that HER2 cleavage and subsequent activation of the p95 subunit is blocked by trastuzumab (Molina et al, 2001) but increased tumour p95 content has also been put forward as an escape mechanism mediating trastuzumab resistance and lapatinib sensitivity (Scaltriti et al, 2007). Therefore, it was hypothesised that the truncated HER2 receptor might not be ideally treated with trastuzumab but rather with agents targeting the intracellular region of the receptor like the tyrosine kinase inhibitor lapatinib (Vazquez-Martin et al, 2011). Although the analysis presented here did not directly measure tumour p95 content or its kinase activity, we can conclude that elevated sHER2 levels have an independent predictive impact on the response to HER2 kinase targeting therapy with lapatinib in the neoadjuvant setting. The effect of combined treatment of lapatinib and trastuzumab on receptor shedding is not clear so far because the GeparQuinto trial did not combine lapatinib and trastuzumab treatment, like for example, the NeoAltto Trial (Baselga et al, 2012).

The pCR rates in our group of patients were lower in the lapatinib group ( $26 \%$ vs $36 \%$ in the trastuzumab group), but the association of sHER2 with treatment response was more prominent with lapatinib. A decline of sHER2 levels during therapy, as well as sHER2 elevation before therapy, was an independent predictor of $\mathrm{pCR}$ in the lapatinib-treated patient group in multivariate analysis. In line with lapatinib treatment in the metastatic setting (Lipton et al, 2011), we could demonstrate that a decline of sHER2 levels early after the start of chemotherapy is relevant.

In our study, an increase of sHER2 levels during NT ( $>20 \%$ ) was seen more often in the lapatinib group $(41 \%$ vs $6 \%$ in the trastuzumab group). This is in line with published data from cell culture experiments showing that sHER2 levels are higher in the presence of lapatinib compared with trastuzumab (VazquezMartin et al, 2011). In the EGF30001 study, metastatic breast cancer patients with a conversion of sHER2 levels from high to low during treatment with lapatinib or placebo plus paclitaxel had a longer progression-free survival than patients with a conversion from low to high during therapy (Finn et al, 2009). In the EGF 20009 study, a decrease of sHER2 levels during the first 16 weeks of lapatinib monotherapy in patients with metastatic breast cancer was associated with better clinical outcome (increased response rate and longer progression-free interval), whereas an increase of $>20 \%$ was associated with worse clinical outcome (Lipton et al, 2011). We could not demonstrate an association of increasing sHER2 levels with lower pCR rates in the lapatinib-treated patient group. Although we were able to show linearity between sHER2 levels and pCR, we could not define a cut-off level for sHER2 levels with an optimum in predicting pCR rates.

In conclusion, this is the first analysis of sHER in the context of lapatinib treatment in the neoadjuvant setting. Our findings support preclinical models indicating different effects of trastuzumab and lapatinib on HER2 receptor shedding. They suggest that elevated baseline sHER2 levels $\left(>15 \mathrm{ng} \mathrm{ml}^{-1}\right)$ and a decrease of sHER2 levels $(>20 \%)$ early after therapy initiation have the potential to predict response to lapatinib treatment.

\section{ACKNOWLEDGEMENTS}

We thank Maila Rossberg and Kati Beck for their excellent technical assistance and the staff of the German Breast Group for their support in this translational research project. Most of all, we thank the patients of the clinical trial GeparQuinto who participated in this substudy.

\section{Conflict of interest}

Advisory role/remuneration: Gunter von Minckwitz (Roche), Holger Eidtmann (Roche), Tanja Fehm (Roche), Joachim Bischoff (Roche), Peter Fasching (Novartis), Brigitte Rack (Roche, Novartis and GlaxoSmithKline), Jens Huober (Roche and GlaxoSmithKline) 
and Volkmar Müller (Amgen, Celgene, Sanofi-Aventis, Pierre-Fabre and Roche). Honoraria: Gunter von Minckwitz (Roche) and Peter Fasching (Novartis). Research funding: Gunter von Minckwitz (GlaxoSmithKline and Roche), Tanja Fehm (Roche, Novartis and GlaxoSmithKline), Joachim Bischoff (GlaxoSmithKline), Peter Fasching
(Novartis), Jens Huober (GlaxoSmithKline) and Volkmar Müller (Roche). The remaining authors declare no conflict of interest.

Supplementary Information accompanies the paper on British Journal of Cancer website (http://www.nature.com/bjc)

\section{REFERENCES}

Ali SM, Carney WP, Esteva FJ, Fornier M, Harris L, Kostler WJ, Lotz JP, Luftner D, Pichon MF, Lipton A (2008) Serum HER-2/neu and relative resistance to trastuzumab-based therapy in patients with metastatic breast cancer. Cancer 113: 1294-1301

Baselga J (2001) Is circulating HER-2 more than just a tumor marker? Clin Cancer Res 7: 2605-2607

Baselga J, Bradbury I, Eidtmann H, Di Cosimo S, de Azambuja E, Aura C, Gomez H, Dinh P, Fauria K, Van Dooren V, Aktan G, Goldhirsch A, Chang TW, Horvath Z, Coccia-Portugal M, Domont J, Tseng LM, Kunz G, Sohn JH, Semiglazov V, Lerzo G, Palacova M, Probachai V, Pusztai L, Untch M, Gelber RD, Piccart-Gebhart M (2012) Lapatinib with trastuzumab for HER2-positive early breast cancer (NeoALTTO): a randomised, open-label, multicentre, phase 3 trial. Lancet 379: 596-598

Buzdar AU, Ibrahim NK, Francis D, Booser DJ, Thomas ES, Theriault RL, Pusztai L, Green MC, Arun BK, Giordano SH, Cristofanilli M, Frye DK, Smith TL, Hunt KK, Singletary SE, Sahin AA, Ewer MS, Buchholz TA, Berry D, Hortobagyi GN (2005) Significantly higher pathologic complete remission rate after neoadjuvant therapy with trastuzumab, paclitaxel, and epirubicin chemotherapy: results of a randomized trial in human epidermal growth factor receptor 2-positive operable breast cancer. J Clin Oncol 23: 3676-3685

Codony-Servat J, Albanell J, Lopez-Talavera JC, Arribas J, Baselga J (1999) Cleavage of the HER2 ectodomain is a pervanadate-activable process that is inhibited by the tissue inhibitor of metalloproteases- 1 in breast cancer cells. Cancer Res 59: 1196-1201

Esteva FJ, Valero V, Booser D, Guerra LT, Murray JL, Pusztai L, Cristofanilli M, Arun B, Esmaeli B, Fritsche HA, Sneige N, Smith TL, Hortobagyi GN (2002) Phase II study of weekly docetaxel and trastuzumab for patients with HER-2overexpressing metastatic breast cancer. J Clin Oncol 20: 1800-1808

Finn RS, Gagnon R, Di Leo A, Press MF, Arbushites M, Koehler M (2009) Prognostic and predictive value of HER2 extracellular domain in metastatic breast cancer treated with lapatinib and paclitaxel in a randomized phase III study. J Clin Oncol 27: 5552-5558

Gianni L, Pienkowski T, Im YH, Roman L, Tseng LM, Liu MC, Lluch A, Staroslawska E, de la Haba-Rodriguez J, Im SA, Pedrini JL, Poirier B, Morandi P, Semiglazov V, Srimuninnimit V, Bianchi G, Szado T, Ratnayake J, Ross G, Valagussa P (2012) Efficacy and safety of neoadjuvant pertuzumab and trastuzumab in women with locally advanced, inflammatory, or early HER2-positive breast cancer (NeoSphere): a randomised multicentre, open-label, phase 2 trial. Lancet Oncol 13: 25-32

Hayes DF, Ethier S, Lippman ME (2006) New guidelines for reporting of tumor marker studies in breast cancer research and treatment: REMARK. Breast Cancer Res Treat 100: 237-238

Hudelist G, Kostler WJ, Attems J, Czerwenka K, Muller R, Manavi M, Steger GG, Kubista E, Zielinski CC, Singer CF (2003) Her-2/neu-triggered intracellular tyrosine kinase activation: in vivo relevance of ligandindependent activation mechanisms and impact upon the efficacy of trastuzumab-based treatment. Br J Cancer 89: 983-991

Köstler WJ, Steger GG, Soleiman A, Schwab B, Singer CF, Tomek S, Brodowicz T, Krainer M, Wiltschke C, Horvat R, Jakesz R, Zielinski CC (2004) Monitoring of serum Her-2/neu predicts histopathological response to neoadjuvant trastuzumab-based therapy for breast cancer. Anticancer Res 24: 1127-1130

Lipton A, Ali SM, Leitzel K, Demers L, Chinchilli V, Engle L, Harvey HA, Brady C, Nalin CM, Dugan M, Carney W, Allard J (2002) Elevated serum her-2/neu level predicts decreased response to hormone therapy in metastatic breast cancer. J Clin Oncol 20: 1467-1472

Lipton A, Leitzel K, Ali SM, Carney W, Platek G, Steplewski K, Westlund R, Gagnon R, Martin AM, Maltzman J (2011) Human epidermal growth factor receptor 2 (HER2) extracellular domain levels are associated with progression-free survival in patients with HER2-positive metastatic breast cancer receiving lapatinib monotherapy. Cancer 117: 5013-5020

MacFarlane RJ, Gelmon KA (2011) Lapatinib for breast cancer: a review of the current literature. Expert Opin Drug Saf 10: 109-121

Mazouni C, Hall A, Broglio K, Fritsche H, Andre F, Esteva FJ, Hortobagyi GN, Buzdar AU, Pusztai L, Cristofanilli M (2007) Kinetics of serum HER$2 /$ neu changes in patients with HER-2-positive primary breast cancer after initiation of primary chemotherapy. Cancer 109: 496-501

McShane LM, Altman DG, Sauerbrei W, Taube SE, Gion M, Clark GM (2005) Reporting recommendations for tumor marker prognostic studies (REMARK). J Natl Cancer Inst 97: 1180-1184

Molina MA, Codony-Servat J, Albanell J, Rojo F, Arribas J, Baselga J (2001) Trastuzumab (herceptin), a humanized anti-Her2 receptor monoclonal antibody, inhibits basal and activated Her2 ectodomain cleavage in breast cancer cells. Cancer Res 61: 4744-4749

Molina MA, Saez R, Ramsey EE, Garcia-Barchino MJ, Rojo F, Evans AJ, Albanell J, Keenan EJ, Lluch A, Garcia-Conde J, Baselga J, Clinton GM (2002) NH(2)terminal truncated HER-2 protein but not full-length receptor is associated with nodal metastasis in human breast cancer. Clin Cancer Res 8: 347-353

Mueller V, Witzel I, Luck HJ, Kohler G, von Minckwitz G, Mobus V, Sattler D, Wilczak W, Loning T, Jaenicke F, Pantel K, Thomssen C (2004) Prognostic and predictive impact of the HER-2/ neu extracellular domain (ECD) in the serum of patients treated with chemotherapy for metastatic breast cancer. Breast Cancer Res Treat 86: 9-18

Scaltriti M, Rojo F, Ocana A, Anido J, Guzman M, Cortes J, Di Cosimo S, Matias-Guiu X, Ramon Y, Cajal S, Arribas J, Baselga J (2007) Expression of p95HER2, a truncated form of the HER2 receptor, and response to anti-HER2 therapies in breast cancer. J Natl Cancer Inst 99: 628-638

Tse C, Gauchez AS, Jacot W, Lamy PJ (2011) HER2 shedding and serum HER2 extracellular domain: biology and clinical utility in breast cancer. Cancer Treat Rev 38: 133-142

Untch M, Fasching PA, Konecny GE, Hasmuller S, Lebeau A, Kreienberg R, Camara O, Muller V, du Bois A, Kuhn T, Stickeler E, Harbeck N, Hoss C, Kahlert S, Beck T, Fett W, Mehta KM, von Minckwitz G, Loibl S (2011) Pathologic complete response after neoadjuvant chemotherapy plus trastuzumab predicts favorable survival in human epidermal growth factor receptor 2-overexpressing breast cancer: results from the TECHNO trial of the AGO and GBG study groups. J Clin Oncol 29: 3351-3357

Untch M, Loibl S, Bischoff J, Eidtmann H, Kaufmann M, Blohmer JU, Hilfrich J, Strumberg D, Fasching PA, Kreienberg R, Tesch H, Hanusch C, Gerber B, Rezai M, Jackisch C, Huober J, Kuhn T, Nekljudova V, von Minckwitz G (2012) Lapatinib versus trastuzumab in combination with neoadjuvant anthracycline-taxane-based chemotherapy (GeparQuinto, GBG 44): a randomised phase 3 trial. Lancet Oncol 13: 135-144

Untch M, Rezai M, Loibl S, Fasching PA, Huober J, Tesch H, Bauerfeind I, Hilfrich J, Eidtmann H, Gerber B, Hanusch C, Kuhn T, du Bois A, Blohmer JU, Thomssen C, Dan Costa S, Jackisch C, Kaufmann M, Mehta K, von Minckwitz G (2010) Neoadjuvant treatment with trastuzumab in HER2-positive breast cancer: results from the GeparQuattro Study. J Clin Oncol 28: 2024-2031

Vazquez-Martin A, Oliveras-Ferraros C, Cufi S, Del Barco S, Martin-Castillo B, Menendez JA (2011) Lapatinib, a dual HER1/HER2 tyrosine kinase inhibitor, augments basal cleavage of HER2 extracellular domain (ECD) to inhibit HER2-driven cancer cell growth. J Cell Physiol 226: 52-57

von Minckwitz G, Eidtmann H, Loibl S, Blohmer JU, Costa SD, Fasching PA, Kreienberg R, Hilfrich J, Gerber B, Hanusch C, Fehm T, Strumberg D, Solbach C, Nekljudova V, Untch M (2011) Integrating bevacizumab, everolimus, and lapatinib into current neoadjuvant chemotherapy regimen for primary breast cancer. Safety results of the GeparQuinto trial. Ann Oncol 22: 301-306

Witzel I, Loibl S, von Minckwitz G, Mundhenke C, Huober J, Hanusch C, Henschen S, Hauschild M, Lantzsch T, Tesch H, Latos K, Just M, Hilfrich J, Barinoff J, Eulenburg CZ, Roller M, Untch M, Muller V (2010) Monitoring serum HER2 levels during neoadjuvant trastuzumab treatment within the GeparQuattro trial. Breast Cancer Res Treat 123: 437-445

This work is published under the standard license to publish agreement. After 12 months the work will become freely available and the license terms will switch to a Creative Commons Attribution-NonCommercial-Share Alike 3.0 Unported License. 